\title{
PSYCHOLOGY
}

\section{PRACTICAL ASPECTS OF THE PROBLEM OF TRAINING SPECIALISTS IN THE SOCIAL SPHERE TO INTERPROFESSIONAL INTERACTION}

\author{
Ph.D. in Psychology, Yana Raievska \\ Ukraine, Kamyanets-Podilsky, Kamyanets-Podilsky National University of Ivan Ogienko, \\ doctoral student of the Institute of Psychology by G. S. Kostiuk, National Academy of Educational \\ Sciences of Ukraine \\ https://orcid.org/0000-0003-3802-2304 \\ Web of Science Researcher ID C-8527-2019
}

DOI: https://doi.org/10.31435/rsglobal_ws/30092019/6703

\section{ARTICLE INFO}

Received: 24 July 2019

Accepted: 11 September 2019

Published: 30 September 2019

\section{KEYWORDS}

specialists in social sphere, professional competence, interprofessional interaction, theoretical-methodological and practical approaches, interdisciplinary approach.

\section{ABSTRACT}

The concept of research is based on the needs of a network of practice bases, based on the use of theories and concepts of psychology, sociology, pedagogy, social work and other humanities, the study of laws and approaches to understanding the content of interprofessional interaction.

The content of the research concept is to develop a procedural model of training professionals in the social sphere to interprofessional interaction and implemented on 2 levels: theoretical-methodological and practical, each of which is represented by a set of scientific approaches.

The methodological basis of the research is systematic, terminological, sociosystematic, structural-activity and synergetic, sociological, and competent methodological approaches.

The result of obtaining future specialists in the social sphere of high-quality vocational education is a set of acquired in the higher educational institution acquired competences in the process of learning: educational-cognitive, interpersonal interaction, communicative, intercultural, socio-cultural and technical (skills).

The structure of the content of vocational education, which includes the following components: social, psychological and pedagogical, methodical, is defined in order to determine the effectiveness of the training of future specialists in the social sphere at a higher educational establishment

Determining the role of interdisciplinary material in the classroom will help to understand the nature of the interaction between the elements of individual disciplines - linear (new knowledge serves to deepen the already acquired); the opposite (new knowledge specifies or directs the assimilated earlier information); problem (new knowledge creates conditions for solving educational problem). Correct building classes will help to understand the nature of content relationships that can be synchronous, reproductive, and promising. In practice, an interdisciplinary approach can be implemented in two main areas: the relationship between different sciences (disciplines), without violating their autonomy, uniqueness, originality; interdisciplinaryism acts as a real tool for the consolidation of sciences (disciplines), the further development of which is crucial for both science and education.

The chosen integration methodological approach of the study does not exclude the trilateral structure of the marked interprofessional interaction in the form of a combination of motivational, target and implementation (executive) planes.

The result of obtaining future specialists in the social sphere of high-quality professional education is a set of acquired in the process of studying in the institution of higher education competencies. This is evidenced, in particular, by the analysis of professionally important competences that, according to respondents, should be characteristic of specialists in the social sphere

The results obtained prompted us to investigate, and what, according to experts, is the basis of interprofessional interaction. 
Citation: Yana Raievska. (2019) Practical Aspects of the Problem of Training Specialists in the Social Sphere to Interprofessional Interaction. World Science. 9(49), Vol.1. doi: 10.31435/rsglobal_ws/30092019/6703

Copyright: (C) 2019 Yana Raievska. This is an open-access article distributed under the terms of the Creative Commons Attribution License (CC BY). The use, distribution or reproduction in other forums is permitted, provided the original author(s) or licensor are credited and that the original publication in this journal is cited, in accordance with accepted academic practice. No use, distribution or reproduction is permitted which does not comply with these terms.

Introduction. Problem statement. Integration of Ukraine into the European educational space, the transition to a competent educational paradigm led to changes in the strategy of training future specialists in the social sphere in higher education, able to navigate well in the realities of the present and react adequately to them, to find the best ways to prevent and overcome emerging problems, to work with high productivity and efficiency, ready for constant personal and professional self-development. In order to achieve the goal of the study there is a need to outline organizational and methodological support for the process of training specialists in the social sphere.

Analysis of recent research. The complexity and multidimensionality of a particular problem identified a wide range of scientific literature in both general psychological and socio-psychological aspects. The basics of professional training are well developed in the theory and methodology of modern pedagogical science, starting with the achievements of Soviet psychologists (S. Rubinstein, O. Leontiev, etc.), and philosophers (G. Batishchev, E. Judin, etc.). The thorough scientific researches in this area include the work of O. Brushlynsky, V. Davydov, I. Zyazyun, O. Pekhoti, and others.

In our opinion, the research on the theoretical and methodological aspects of social work as a scientific theory, academic discipline and professional activity is worthy of attention, in particular: V. Andrushchenko, O. Bezpalko, I. Bogdanova, V. Bocharova, R. Vainola, L. I. Guslyakova, I. Zvereva, I. Zimnya, A. Kapskaya, O. Karpenko, I. Kovchina, I. Kozubskaya, V. Kurbatov, G. Laktionova, G. Lokareva, L. Myshchyk, V. Polischuk, S. Kharchenko Y. Kholostova, O. Yaremenko; professional training of specialists in social work (Y. Berezkin, V. Bocharova, T. Demidova, A. Derkach, V. Zhukov, I. Isaev, T. Kiselev, E. Klimov, D. Connor, L. Kononova, I. Lavrenenko, A. Markov, K. Rogers, D. Seymour, E. Silyaev, L. Starovoitova, L. Topchiy, N. Tsvetkova, E. Kholostova, etc.); the formation of their professional culture (M. Firsov); features of professional and personal development (N. Klushin, N. Shmelev); to interact with different categories of clients (L. Ivanova, Y. Matskevich, L. Pinchuk, R. Chubuk, V. Leonov, O. Mikhailenko, N. Shpig, M. Yaroshko, etc.); formation of readiness of future specialists of social sphere for organization and implementation of various directions of professional activity (A. Vedmedyuk, S. Grishak, T. Lesina, O. Lugantseva, M. Mal'kov, S. Pashchenko, O. Platonova, O. Pozhidayeva, O. Tyutyunnik, I. Trubavina, O. Fil, O. Sharovatova).

The purpose of the paper is to identify the main features of the practical aspects of training specialists in the social sphere to interprofessional interaction; to identify the current trends in the application of principles, forms, methods of social work and interdisciplinary approach in the training of specialists in the social sphere to interprofessional interaction.

Theoretical analysis. The analysis of scientific works and modern practice makes it possible to distinguish and characterize such leading principles of organizational and methodological support of the process of training specialists in the social sphere: the basic principles of the theory of knowledge: objectivity, scientific, historicism, an integrated approach to the study of social reality phenomena; the fundamental training of specialists in the social sphere, which in its content provides a thorough assimilation of system knowledge, which is the basis of development, and in the future - their own professionalism; continuity and continuity in the construction of the content of education, which contributes to the definition of effective approaches to the application of innovative techniques and technologies for its implementation at all levels of specialization; Problems and innovations in the organization and implementation of high-quality education of future specialists in the social sphere; communicative and intercultural interaction, the application of which ensures the effective formation of skills and competences for the purpose of diverse intercultural communication; provision of international standard level of training as one of the important indicators of the quality of mastery by future specialists in the social sphere, which meet the objective international standard methods of evaluation.

Accordingly, the concept of research is based on the needs of the network of practice bases, based on the use of theories and concepts of psychology, sociology, pedagogy, social work and other humanities, 
the study of laws and approaches to understanding the content of interprofessional interaction. The content of the research concept is to develop a procedural model for training professionals in the social sphere to interprofessional interaction and implemented on 2 levels: theoretical, methodological and practical, each of which is represented by a set of scientific approaches.

Consequently, the result of obtaining future specialists in the social sphere of high-quality professional education is a set of acquired competences in the higher education institution acquired during the education process:

- educational and cognitive that enables to improve educational activities, increase the efficiency of their learning and productivity of use, contain general competences (knowledge), in particular: general knowledge about social systems and general doctrines; knowledge of different approaches to the interpretation of cultural facts; sufficient level of knowledge of anthropological, sociological knowledge, psychological and sociological and historical information related to the concept of interprofessional interaction; knowledge of geopolitical concepts; understanding the essence of secularism and its consequences; knowledge of approaches in philosophy related to tolerance, pluralism, social justice, particularism and universalism; knowledge of legal and administrative mechanisms for regulating social processes; knowledge of political and social aspects, client rights at international, European and national levels; general knowledge of cultural differences in views on basic values (parenthood, gender relations, upbringing of children, etc.); understanding of the various terminological components of the "interprofessional" category (integration, identity, diversity, assimilation, acculturation, ethnocentrism, ethnization, inculturation, tolerance, mediation, multiculturalism, racism, empathy, relativism, etc.);

- interpersonal interaction, which contains skills of active and reflexive listening skills; ability to distance themselves from their own stereotypes; possessing a palette of tools for establishing interaction with representatives of other cultures; the ability to assess the client's attitude to the problem situation, the social worker himself, the willingness to reorganize the situation in order to improve the interaction; ability to identify and mobilize customer resources; ability to pause in time to analyze the situation; the ability to identify the client as a reliable source of information, having his own vision of his or her own situation;

- the communicative, the formation of which ensures the ability of the person by means of language to carry out subject-subjective interaction in the educational space of higher and beyond, which contains the ability to define and schematically recreate the system of communicative codes of the client; the ability to diagnose difficulties that may arise in the context of intercultural interaction; Ability to ensure mutual understanding throughout the cooperation with the client; the ability to inform the client about the forms of social intervention, his social rights, taking into account the possibilities of understanding the information provided to him in the context of personal, group or community cultural specifics; the ability to define ethnocentric expressive communicative elements that are important or insignificant in different situations; ability to combine the symbolic, ethical and subjective context of communication taking into account all aspects of communication interaction (client, social worker, institution, society); the ability to feel the limits of permissible and forbidden in intercultural interaction;

- intercultural, which in its essence is an indicator of the formation of the ability of a future specialist in the social sphere to effectively participate in interprofessional communication at different levels of its implementation;

- socio-cultural, which contributes to the formation of systematic and profound knowledge of another culture, the study and understanding of the traditions and realities of the country or peoples;

- technical (skills) - ability to facilitate communication between professionals and clients, clients themselves through cross-cutting competencies of professional activity, and not specific, specific to work only with a specific target group; the ability to analyze complex situations taking into account the cultural context; possession of tools to solve problems caused by interaction; possession of techniques and techniques of social intervention (diagnosis, mediation, personal support, social orientation, mediation, etc.); ability to actualize and apply specific professional skills to take into account the cultural context of the situation; sufficient awareness of possible "pitfalls" in a situation of interprofessional interaction (relativism, ethnicity, domination, etc.).

In order to determine the effectiveness of training future specialists in the social sphere in a higher educational institution, the structure of the content of vocational education, which includes the following components: social - reveals an understanding of the person's perception of the influence of culture on the behavior of its representatives, thereby disclosing the social significance of intercultural interaction in the development of a particular community or society in in general, and the creation of an intercultural environment for peace and reconciliation; psychological and pedagogical - characterizes the awareness of 
specialists in the social sphere of the differences between representatives of a particular culture (stereotypes of behavior, actions, mentality), the values of another culture, the formation of abilities and skills to effectively adapt to certain cultural conditions and to establish effective intercultural communication; methodical - implies the availability of appropriate forms, methods and a set of pedagogical means that facilitate the implementation of the content of foreign language training and the formation of intercultural competence in the training of future professionals in the social sphere.

The structure of training specialists in the social sphere requires scientific, methodological substantiation, reassessment and substantiation of the acquired experience, which have departments of social work; studying and transforming into a system of domestic professional training of foreign experience; Improvement of the State sectoral standard for training specialists in the social sphere; revision of curricula that have a large number of small in-volume curricula; theoretical orientation and separation from practical problems that appear in society; reviewing the list of practices during student training; The urgent need to take into account the specialization and the mobility of the training itself.

Methodology. In the early stages of social and professional development, future specialists in the social sphere begin to comprehend their life choices, see their connection with the goals and objectives of the chosen profession, find the necessary conditions for successful acquisition of the relevant skills and skills, and are involved in specially organized activities for the development of their own socially-professional guidance and experience. That is why the methodological basis of the study is systemic, terminological, sociosystem, structural and activity and synergetic, sociological, and competent methodological approaches.

In particular, the use of a systematic approach provides an opportunity to consider interprofessional interaction as an object of activity of specialists in the social sphere; the terminological approach contributes to the formation of the conceptual-categorical apparatus of the study; the synergetic approach allows us to trace the genesis of the system of professional training of specialists in the social sphere to interprofessional interaction; the sociological approach provides a perspective on the basis of the specifics of the activities of specialists in the social sphere to substantiate the structural and functional model of the personal trajectory of training specialists of the social sphere for interprofessional interaction; the competent approach creates the conditions for considering the competence of specialists of the social sphere from interprofessional interaction as a result of integration of knowledge, skills acquired during the study of disciplines of professional training; interdisciplinary approach, which necessitates the use of theoretical positions of other humanities - sociology, psychology, ethnography, law, social work.

We believe that determining the role of interdisciplinary material in the classroom will help to understand the nature of the interaction between the elements of individual disciplines - linear (new knowledge serves to deepen the already acquired); the opposite (new knowledge specifies or directs the assimilated earlier information); problem (new knowledge creates conditions for solving educational problem). The correct construction of the classroom will help to understand the nature of content relationships that can be synchronous (the material of related disciplines is processed simultaneously), reproductive (to rely on assimilated from other subjects), perspective (a certain issue is considered only in the main features with an orientation to a more detailed study in the classroom from another subject).

Formation of professional readiness of specialists in the social sphere should be carried out through the established relationship between such educational disciplines as "Technologies of social work", "Social work with different categories of clients", "Applied methods in social work", "Legal support of the system of social protection" "Social design", "Social work in the field of employment", "Management of social work", "Methods of accrual of social benefits", etc. In order to understand the causes and possible factors of the appearance of poverty and poverty, social risks that lead to total or partial loss of working capacity, which causes the loss of labor or other types of income, may be necessary, it is necessary to find out the causes and consequences of the impact of socioeconomic processes on social well-being. of society, which, in turn, is impossible without the economic knowledge and knowledge of normative legal acts regulating the provision of social assistance, benefits, subsidies, financial compensation for persons who have been in c Ok circumstances. Therefore, it is necessary to build a process of training future specialists in the social sphere to provide social and economic services to clients through the application of integration of knowledge from different disciplines in the process of interprofessional interaction. The logic of the description of the proposed condition requires the creation of a structure of interprofessional interaction from the position of training future specialists in the social sphere to provide clients with various types of services that would disclose interdisciplinary integration.

In practice, an interdisciplinary approach can be implemented in two main areas. For the first, most widespread, interdisciplinarity establishes links between different sciences (disciplines), 
informally unites them without violating their independence, uniqueness, originality. In the second approach, interdisciplinarity appears as a real tool for the consolidation of sciences (disciplines), the emergence of integrated products, projects, interdisciplinary research objects, the further mastering of which is crucial for both science and education.

In modern practice, the teaching of the disciplines of professional training of specialists in the social sphere using an interdisciplinary approach is effective in terms of assimilation of theoretical knowledge and acquiring practical skills, the following methods, forms and techniques can be defined: brainstorming ("brainstorming"); "Tree of solutions"; discussion with the invitation of specialists; business game; Commenting, evaluation (or self-assessment) of participants' actions; master classes; method of analysis and diagnostics of the situation; project method; modeling; PRES formula (from the English Position - Reason - Explanation or Example - Summary) - a method aimed at developing and consolidating skills of argumentation, substantiation and protection of own position in the discussion, dialogue, during business meetings; problem method; public speaking; work in small groups; interdisciplinary trainings.

It should be noted that the chosen integration methodological approach of the study does not exclude the trilateral structure of the defined interprofessional interaction in the form of a combination of motivation, target and implementation (executive) planes, in particular:

1. A motivational plane can be represented in the form of macro-intentions - general interpersonal intentions that have a personality-professional character and can combine the entire discourse of interprofessional interaction of future professionals in the social sphere. The indicated macro-intentions, in turn, are characterized by: the social orientation of discourse - both in relation to the simple thesaurus, and in relation to the whole semantic load of communications; the professional content of the interaction and its intentions, focus on the main social problems with which a specialist in the social sphere will deal; personal motivation to master the profession (with a relative share of professional interests and the desire to know for reasons that are not directly related to the future specialty).

2. The target area of training a specialist in the social sphere in the context of the study embodies the idealized result of training future specialists in the social sphere - a high level of professional competence. After all, the broad interpretation of the concept of "social sphere" can define this plane in several aspects - invariant (purely professional) and variational (person-interacting). In other words, the statement of the ultimate goal of forming the interprofessional interaction of students determines the ways of its achievement, and is embodied in the executive plane of professional activity.

3. The executive plane is a dynamic set of concrete actions and operations for the formation of a designated competence in the process of training a specialist in the social sphere - in the classroom or non-auditing form.

We consider it expedient to introduce in the process of training future specialists of the social sphere of continuous practical training, from the first year of study to the end of the higher educational institution.

Results. An important condition for the professional activity of a specialist in the social sphere in the present conditions is their level of awareness about interprofessional interaction. The following groups of respondents participated in the survey: the students of the first course - 50 people, the students of the second year - 62, the students of the 3rd year - 54 persons, the bachelors -300 , the masters - 200 people, specialists - 180 people. The results of the survey showed a low level of awareness of interprofessional interaction (Table 1).

According to the results of empirical research, in particular author's methodology concerning the professional activity of a specialist in the social sphere in the context of interprofessional interaction, the level is also low. So, to the question how often in your professional activities you turn to other professionals, the results are distributed as follows: very often $-0 \%$, often - $20 \%$, sometimes $-40 \%$, never $-40 \%$. Intensity of appeal to specialists of other branches in solving problems was below the average $-60 \%$. Difficulties that arise when dealing with specialists from other industries are: concealing information - 30\%, ignorance of the way of solving the problem - 50\%, lack of desire to solve the problem - $20 \%$. The effectiveness of solving the problem depends on: the desire of other professionals $-50 \%$, the possibilities of specialists $-20 \%$, the level of professional competence - $60 \%$, state sectoral standards - $50 \%$. The disadvantage in the legal documents on interprofessional interaction of specialists in the social sphere is the lack of a legislative framework for regulation of interprofessional cooperation and the unclear distribution of the rights and responsibilities of specialists. The reasons for the absence of interprofessional cooperation in the professional activity are: an effective way to solve the problem - $10 \%$, competition between specialists - $30 \%$, protective mechanism (this is not mine, but yours) - $10 \%$, struggle for own resources - $25 \%$, the struggle for power $15 \%$. Specialists deal with responsibility and conscience - $20 \%$, with interest and activity of $20 \%$, with 
selectivity and necessity - 20\%, taking into account the emotional attitude (affection, dislike, love, sympathy - antipathy, etc.) to a person - $40 \%$, as awareness of duty - $20 \%$, neutral $-20 \%$.

Table 1. Level of awareness of interprofessional student interaction 1-3 courses, bachelors, masters and professionals in the social sphere

\begin{tabular}{|c|l|c|c|c|}
\hline \multirow{2}{*}{ № } & \multicolumn{3}{|c|}{ Levels } \\
\cline { 3 - 5 } & & high, $\%$ & middle, $\mathbf{\%}$ & low, $\%$ \\
\hline 1. & students of the first course & 0 & 0 & 100 \\
\hline 2. & students of the second year & 0 & 16,1 & 83,9 \\
\hline 3. & students of the 3rd year & 0 & 33,3 & 66,7 \\
\hline 4. & bachelors & 10 & 31,3 & 58,7 \\
\hline 5. & masters & 18 & 32 & 50 \\
\hline 6. & specialists & 22,2 & 33,3 & 44,5 \\
\hline
\end{tabular}

According to the methodology, O. Bondarchuk and L. Karamushka established disharmonious motives of interprofessional interaction among specialists in the social sphere. It was found that the most significant for the specialists of the social sphere are prestigious motives - on average 12.8 points, social ones - an average of 11.3 points, personal and professional growth - an average of 11 points), pragmatic an average of 10.3 points and actually professional motives - an average of 10 points.

The professionalism of a specialist in the social sphere consists of professional knowledge, skills and abilities. Mastering skills and abilities is an integral part of the practical training of specialists, the formation of which is usually carried out during the workshops, as well as during continuous practice. The result of obtaining future specialists in the social sphere of high-quality professional education is a set of acquired in the process of studying in the institution of higher education competencies. This is evidenced, in particular, by the analysis of professionally important competences that, according to respondents, should be characteristic of specialists in the social sphere (Table 2).

Thus, the most demanded experts consider the competence of interpersonal interaction $(86.8 \%)$, which contains the skills of active and reflexive listening skills; ability to distance themselves from their own stereotypes; possessing a palette of tools for establishing interaction with representatives of other cultures; the ability to assess the client's attitude to the problem situation, the social worker himself, the willingness to reorganize the situation in order to improve the interaction; ability to identify and mobilize customer resources; ability to pause in time to analyze the situation; the ability to identify the customer as a reliable source of information, having his own vision of his own situation and technical skills $(89,7 \%)$, which will facilitate communication between professionals and clients, by clients themselves through cross-cutting competencies of professional activity, rather than specific, specific to work only with a specific target group; the ability to analyze complex situations taking into account the cultural context; possession of tools for solving problems caused by interaction; possession of techniques and techniques of social intervention (diagnosis, mediation, personal support, social orientation, mediation, etc.); the ability to actualize and apply specific professional skills to take into account the cultural context of the situation; sufficient awareness of possible "pitfalls" in a situation of interprofessional interaction (relativism, ethnicity, domination, etc.).

Table 2. The distribution of the researchers concerned with the recognition of professional competencies of social specialists

\begin{tabular}{|l|l|c|}
\hline № & $\begin{array}{l}\text { "Professional-important competences of a specialist in the social } \\
\text { sphere are ..." }\end{array}$ & Result, \% \\
\hline 1. & educational and cognitive & 67,6 \\
\hline 2. & interpersonal interaction & 86,8 \\
\hline 3. & communicative & 58,8 \\
\hline 4. & intercultural & 78,7 \\
\hline 5. & socio-cultural & 56,5 \\
\hline 6. & technical (skills) & 89,7 \\
\hline
\end{tabular}

The results obtained prompted us to investigate, and what, according to experts, is the basis of interprofessional interaction (Table 3). 
Table 3. Distribution of investigated specialists on the peculiarities of understanding the essence of interprofessional interaction in the social sphere

\begin{tabular}{|c|l|c|}
\hline № & $\begin{array}{l}\text { "What is the basis of interprofessional interaction of a specialist in } \\
\text { the social sphere?" }\end{array}$ & Result, \% \\
\hline 1. & $\begin{array}{l}\text { highly qualified specialist (professional and personal skills and } \\
\text { qualities), fulfillment of his professional duties }\end{array}$ & 69,3 \\
\hline 2. & regulatory support, legal knowledge & 39,8 \\
\hline 3. & mutual respect, trust, humane, benevolent attitude to people, empathy & 78,5 \\
\hline 4. & $\begin{array}{l}\text { mutual understanding with others, readiness to interact, ability to } \\
\text { establish contact }\end{array}$ & 91,2 \\
\hline 5. & coherence of action and common goal, interaction performance & 77,5 \\
\hline 6. & activity, openness, openness, readiness for change & 34,1 \\
\hline 7. & $\begin{array}{l}\text { self-education, self-development and self-development, aspiration for } \\
\text { self-realization in the social sphere }\end{array}$ \\
\hline 8. & motivational interest & 41,3 \\
\hline 9. & ntegration, development of the latest technologies & 36,3 \\
\hline
\end{tabular}

Thus, it was discovered that the specialists in the opinion of the most noteworthy are the mutual understanding with others (including with clients), skills and ability to establish contact (listen, hear and understand other people) and constantly support them $(91.2 \%)$; self-respect, trust, humanity, friendly attitude towards others, empathy, etc. (78.5\%) and coherence of action, common goal, productivity of interaction (77.5\%). The alarming data on the number of subjects who do not pay attention to the activity, openness, openness of the client, its readiness for change $(54.1 \%)$, that is, experts recognize only their own activity. A significant difference was found among the respondents who paid little attention to such factors as: "motivational interest" (41.3\%), "normative legal support, legal awareness" (39.8\%), "self-education, self-improvement and self-development, aspiration to selfrealization in the social sphere "(39.4\%), which indicates a low level of legal awareness, lack of desire to acquire and improve knowledge, skills and professional skills.

Conclusions. However, a thorough analysis of scientific works and empirical materials allows us to state that there is no systematic theoretical and methodological and scientific and technological support for the preparation of future social workers for practical work. However, experience shows that the educational process in the process of training specialists in the social sphere today has many opportunities for solving these problems. At the same time, these opportunities in higher educational institutions are not yet used at full capacity, as evidenced by a number of contradictions between:

- the need to take into account interprofessional interaction and implementation of interdisciplinary approaches in the content, organization of social work with different groups of the population and lack of appropriate professional training of specialists in the social sphere who carry out this activity;

- an essential social need for egalitarian thinkers of interprofessional integration, able to withstand obsolete stereotypes, and the inadequate level of education;

- the objective needs of the society in professionally competent social workers, the uniqueness of the requirements for their activities and the extent of scientific development of the problem of the formation of professional competence; existing in the practice of training specialists in the social sphere by a unified, well-established system of training a social worker and personally oriented character of social work with various objects;

- the needs of society and the individual in the radical transition from the informational and projective teaching method to the activity, functional-target approach and the actual readiness for practical social work in the social sphere;

- the traditional system of teaching psychological and pedagogical disciplines and professional techniques in isolating them from each other and the need for the implementation of integrated links between them in order to enhance the effectiveness of learning;

- awareness of the future specialists about the necessity and significance of the development of professional competence and insufficient experience, the level of formation of their practical skills in the field of social work;

- unreasonably limited terms of direct practical training of future specialists - the timing of future professional practice in the workplace, which plays the role of consolidating and checking their knowledge and skills.

The need for solving these contradictions requires a rethinking of theoretical and methodological principles and conceptual and methodological approaches to the preparation of a modern social worker, the 
formation of his professionalism in accordance with the requirements of a personally oriented paradigm of higher professional education; rapid changes in the field of practical activity of specialists and the need for institutions of higher education to introduce in the educational process new pedagogical technologies that have an educational, stimulating character, on the one hand, and a significant lag in the content, forms and technologies of their professional training, on the other.

\section{REFERENCES}

1. Karpenko O.H. (2014) Teoriia i praktyka profesiinoho stanovlennia sotsialnoho pratsivnyka : navch. posib. Kyiv: Vydavnychyi Dim «Slovo». $192 \mathrm{~s}$.

2. Melnyk L.P., Raievska Ya.M., Melnyk Zh.V. (2019) Prohrama i metodychni rekomendatsii tekhnolohichnoi praktyky: dlia studentiv haluzi znan 23 Sotsialna robota spetsialnosti 231 Sotsialna robota za osvitnoiu prohramoiu Sotsialna robota (denna ta zaochna forma navchannia); dlia studentiv haluzi znan 23 Sotsialna robota spetsialnosti 232 Sotsialne zabezpechennia za osvitnoiu prohramoiu Sotsialna dopomoha (denna forma navchannia). Kamianets-Podilskyi: Kamianets-Podilskyi natsionalnyi universytet imeni Ivana Ohiienka. $54 \mathrm{~s}$.

3. Raievska Ya.M. (2019) Osoblyvosti zdiisnennia mizhdystsyplinarnoho pidkhodu v protsesi pidhotovky fakhivtsiv sotsialnoi sfery do mizhprofesiinoi vzaiemodii. Zbirnyk naukovykh prats Kamianets-Podilskoho natsionalnoho universytetu imeni Ivana Ohiienka. Kamianets-Podilskyi: Medobory-2006, Vyp. XXXIII. S.123-133.

4. Chubuk R. V. (2014) Problemy profesiinoi pidhotovky maibutnikh fakhivtsiv sotsialnoi sfery u vyshchii shkoli. Visnyk Chernihivskoho natsionalnoho pedahohichnoho universytetu imeni T. H. Shevchenka. Chernihiv, Vyp. 115. 256-259. 